\title{
Influence of climatic factors on the medical attentions of dermatologic diseases in a hospital of Lima, Peru
}

\author{
Influência de fatores climáticos no tratamento médico de doenças \\ dermatológicas em um hospital em Lima, Peru \\ Ericson L. Gutierrez ${ }^{1}$ \\ Carlos Galarza ${ }^{2}$ \\ Maybbe Mendoza ${ }^{4}$ \\ Alex G. Ortega-Loayza ${ }^{6}$
}

Willy Ramos ${ }^{3}$

María E. Smith ${ }^{5}$

\begin{abstract}
BACKGROUND: Significant associations have been described between climatic factors and human health, which can occur in dermatologic diseases too.

OвJестіvE: To determine the influence of the climatic factors on the medical attentions of dermatologic diseases in a general hospital in Lima (Peru). PATIENTS AND METHODS: Observational study which was carried out in a national hospital between January 2004 and December 2007. The diagnoses were classified according to the ICD-10 system. The climate information was provided by the National Oceanographic and Atmospheric Administration from USA (NOAA).

RESULTS: 3294 patients were included in the study, the average age was $35.4 \pm 20.7$ years old, and 53.2\% were females. The "El Niño" phenomenon was associated with an increase in the prevalence of actinic keratosis $(p=0.002)$, viral warts $(p=0.001)$ and rosacea $(p=0.014)$. The "La Niña" phenomenon was associated with a reduction in viral warts $(p=0.026)$. Spring was associated with an increase of dermatitis $(p=0.003)$, and summer was associated with an increase of benign neoplasms $(\mathrm{p}=0.049)$.

Conclusion: The climatic variations influenced the occurrence of certain dermatologic diseases. The present study may represent an orientation guide to specialists and general practitioners identifying the most common dermatologic diagnoses and thus enabling better preparation to treat these cases in determined seasons of the year.
\end{abstract}

Keywords : El Niño; El Niño Oscilation South; La Niña Phenomenon

Resumo: FunDAMENTO: Associações significativas entre fatores climáticos e saúde humana têm sido descritas, inclusive na área de Dermatologia.

OBjetivo: Determinar a influência de fatores climáticos no tratamento de doenças dermatológicas em um hospital em Lima (Peru).

PACIENTES E MÉTODOS: Estudo observacional realizado em um hospital em Lima entre janeiro de 2004 e dezembro de 2007. Os diagnósticos foram classificados de acordo com o sistema ICD-10. Informações climáticas foram fornecidas pela "National Oceanographic and Atmospheric Administration" (NOAA - USA).

RESUltAdOS: 3.294 pacientes participaram do estudo. A idade media foi $35.4 \pm 20.7$ anos e 53,2\% eram mulheres. O fenômeno "El Niño" foi associado a um aumento da prevalência de queratose actínica $(p=0,002)$, verrugas virais $(p=0,001)$ e rosácea $(p=0,014)$. O fenômeno "La Niña" foi associado a diminuição das verrugas virais $(p=0,026)$. A primavera foi associada a um aumento de dermatite $(p=0,003)$ e $o$ verão, a um aumento de tumores benignos $(p=0,049)$.

CONCLUSÃO: Variações climáticas influenciam o aparecimento de algumas doenças dermatológicas. O presente trabalho pode orientar especialistas e clínicos gerais por meio da identificação dos diagnósticos dermatológicos mais comuns e, consequentemente, prepará-los para tratar doenças sazonais.

Palavras-chave: El Niño; El Niño Oscilação Sul; El Niño; Fenômeno la Niña

Recebido em 01.02.2009.

Aprovado pelo Conselho Consultivo e aceito para publicação em 27.04.10.

* Work conducted at the Institute of Clinical Investigation, National University of San Marcos (UNMSM) - Lima, Peru, and Department of Internal Medicine, Virginia Commonwealth University, Richmond, VA, USA.

Conflict of interest: None / Conflito de interesse: Nenbum

Financial funding: None / Suporte financeiro: Nenbum

MD; Institute of Clinical Investigation, National University of San Marcos (UNMSM) - Lima, Peru.

MD; Institute of Clinical Investigation, National University of San Marcos (UNMSM) - Lima, Peru.

MD; Institute of Clinical Investigation, National University of San Marcos (UNMSM) - Lima, Peru.

MD; Institute of Clinical Investigation, National University of San Marcos (UNMSM) - Lima, Peru.

MD; Medical Resident, Department of Internal Medicine, McLaren Regional Medical Center, Flint - MI, USA.

MD; Medical Resident; Institute of Clinical Investigation, National University of San Marcos (UNMSM) - Lima, Peru. Department of Internal Medicine. Virginia Commonwealth University, Richmond, VA, USA 


\section{INTRODUCTION}

Previous studies have shown the influence of climatic factors on the occurrence of different dermatologic diseases. Hellier showed an increase in the frequency of dermatitis and rosacea and a decrease in urticaria during the spring season. ${ }^{1}$ Hancox observed a seasonal variation tendency for actinic keratosis, vulgar acne, foliculitis, psoriasis, dyschromias, seborrheic dermatitis and seborrheic keratosis. ${ }^{2}$ Recently, Jha found a seasonal variation in the occurrence of vulgar acne, melasma, contact dermatitis, scabies, photo-dermatitis and vitiligo. ${ }^{3}$

Lima is located in the central region of South America, to the west of the Andes, with an average altitude of 133 meters above sea level. It has an average temperature of 16.8 to $17.8^{\circ} \mathrm{C}\left(62\right.$ to $\left.64^{\circ} \mathrm{F}\right)$. The relative humidity reduces the penetrance of sunlight, especially in populated and industrialized towns. ${ }^{4}$ Also, Peru has four climatic seasons: summer, fall, winter and spring, with the former starting at the summer solstice on December $21^{\text {st }}$. However, the transition from one season to another does not occur in a uniform way because of the "El Niño" and "La Niña" phenomena, which cause a variation in expected meteorological conditions in certain times of the year. The "El Niño" phenomenon produces a generalized increase in the sea surface temperature over the eastern and central parts of the Equatorial Pacific. ${ }^{5}$ It is associated with changes in atmospheric pressure, producing a drop in the Southeastern Pacific and a rise in Oceania, ${ }^{6}$ and also with an increase in the environmental temperature of the Peruvian coast. On the other hand, the "La Niña" phenomenon behaves in the opposite way, being considered by many as the "Anti-Niño" phenomenon.

A previous study in Lima showed a significant increase in dermatologic diseases such as tinea, pityriasis versicolor, miliaria and foliculitis when the environmental temperature raises an average of $1.6^{\circ} \mathrm{C}$ as a conse- quence of the "El Niño" phenomenon. It also showed that the frequency of dermatitis, scabies, psoriasis and papular urticaria as reasons for consultation decreased.

The aim of this study was to determine the influence of the climatic factors such as the "El Niño" and "La Niña" phenomena, air temperature and climatic seasons on dermatologic diseases diagnosed in a national hospital of Lima between January 2004 and December 2007.

\section{PATIENTS AND METHODS}

This was an observational study carried out in a national hospital in Lima, Peru between January, 2004 and December, 2007. All new patients presenting to the dermatology clinic during that period were included. The gender, age, dermatologic diagnosis and month of medical attention were recorded for each patient. The patients who had more than one dermatologic condition were considered as independent cases. The diagnoses were classified in different groups according to the International Classification for Diseases (ICD-10). When necessary, direct microscopic examinations and skin biopsies were performed to confirm diagnosis.

The average temperature was obtained from the Monthly Climatic Data for the World Publication, given by the National Oceanographic and Atmospheric Administration in USA (NOAA). The Oscillation Niño Index $(\mathrm{ONI})^{9}$ was used to define the periods of the "El Niño/La Niña" phenomena.(Figures 1,2 and 3) This indicator is based on the quarterly average of the climate anomalies in the temperature of the sea surface $\left[{ }^{\circ} \mathrm{C}\right]$ of the El Niño 3.4 region $\left(5^{\mathrm{O}} \mathrm{N}-5^{\mathrm{O}} \mathrm{S}, 120^{\mathrm{O}}-170^{\mathrm{O}} \mathrm{W}\right)$, calculated by the program ERSST.v3.

The events called "El Niño" include five consecutive months of anomalies $0.5^{\circ} \mathrm{C}$ greater above the average temperature, and result in an increase in the sea surface temperature. On the other hand, the events called "La Niña" present as anomalies $0.5^{\circ} \mathrm{C}$

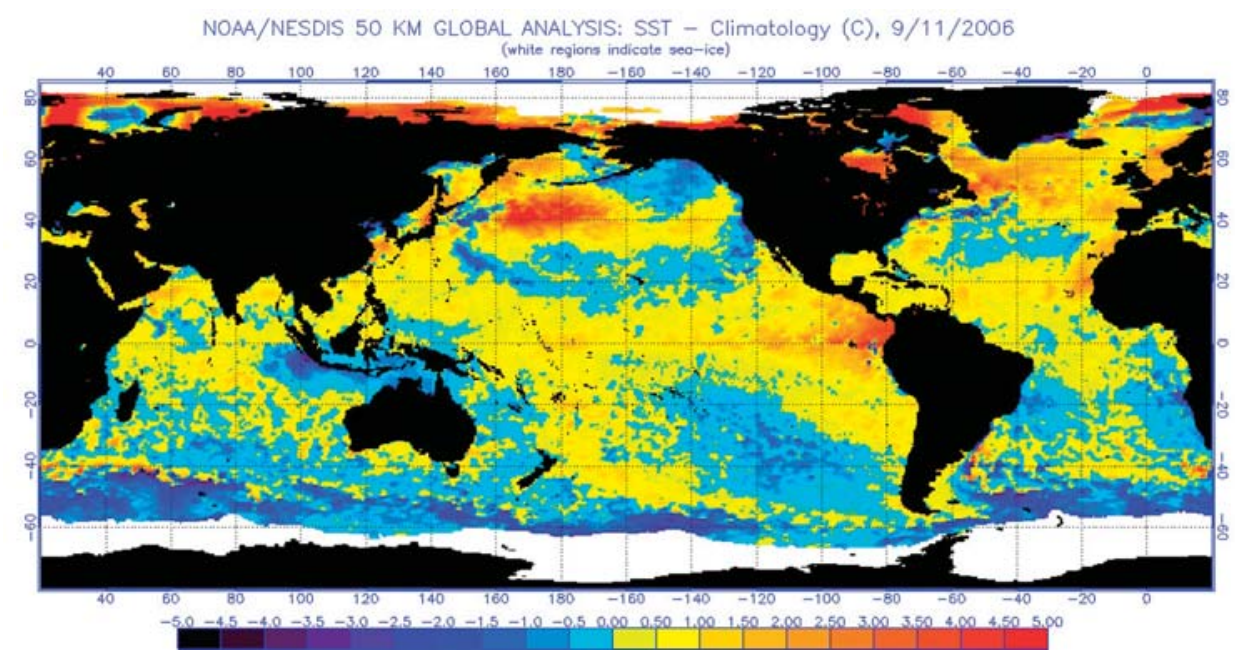

Figure 1: The Oscillation Niño Index(ONI) and the "El Niño" phenomenom 


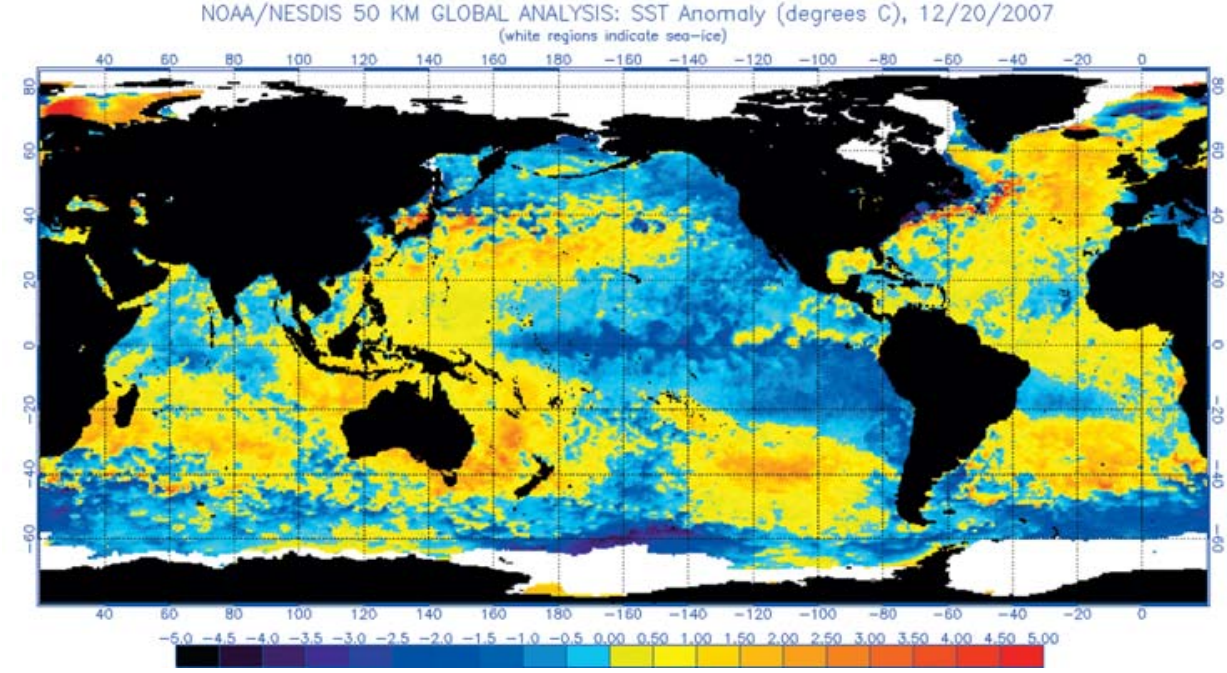

Figure 2: The Oscillation Niño Index(ONI) and the "La Niña" phenomenom below the average during 5 consecutive months and result in a decrease in the temperature of the sea surface. According to this index, the events can be classified as weak (with anomalies ranging from 0.5 to $0.9^{\circ} \mathrm{C}$ in the sea surface temperature (SST), moderate (1.0 to 1.4$)$ and strong (>1.4).

The months were classified according to the presence or absence of the "El Niño/La Niña" phenomena (ONI), and the phenomena were characterized as weak, moderate, or strong. The seasons were defined as summer (January, February, and March), fall (April, May, and June), winter (July, August, and September) and spring (October, November, and December).

A database was created using the SSPS program version 15.0 (SPSS 15.0, Chicago, IL), univariate statistics based on calculations of frequencies, percentages and central and dispersion tendency measurements were used as well as bivariate statistics such as chi-square test for qualitative variables Those variables that were statistically significant were analyzed by Forward conditional logistic regression. The calculations were made with a 95\% confidence level.

\section{RESULTS}

A total of 3294 new patients were included. The average age was $35.4 \pm 20.7$ years (range: 1 month to 94 years old) and the age group of $16-30$ years old was the most prevalent (30\%); 53.2\% were females and $46.8 \%$ were males (Table 1 ).

CLIMATIC PHENOMENA: The majority of patients were seen during summer season (37.6\%); $30.9 \%$ were seen during the appearance of the "El Niño" phenomenon and $7.1 \%$ during the "La Niña" phenomenon (Table 2).

DERMATOLOGIC DIAGNOSES: By group, the infectious dermatoses were the most common (29.3\%), followed by dermatitis (17.7\%), benign neoplasms (9.9\%) and disorders of skin appendages (9.8\%). The most frequent skin disorders found were viral warts (14.3\%), vitiligo (6\%) and acne (4.8\%) (Table 3).

CLIMATIC PHENOMENA AND DERMATOLOGIC DISEASES: In the Analysis with Forward conditional

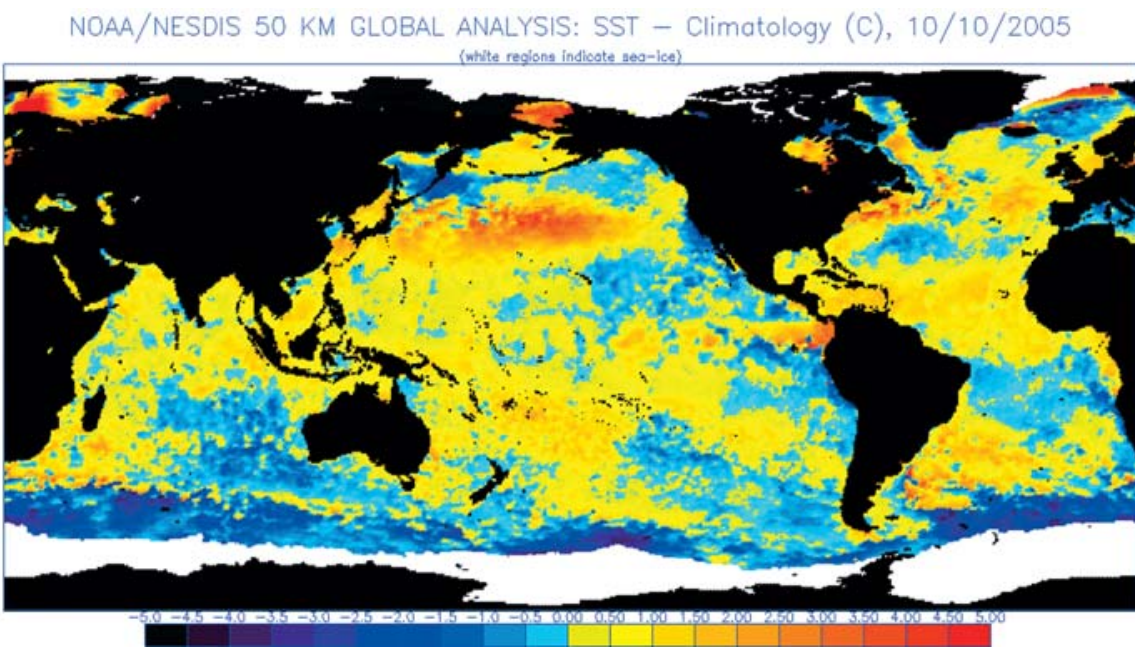

Figure 3: The Oscillation Niño Index(ONI); neutral conditions 
TABLE 1: Distribution of patients seen between January 2004 and December 2007

\begin{tabular}{|c|c|c|c|c|c|c|}
\hline \multirow[b]{2}{*}{ AGE- GROUPS } & \multicolumn{6}{|c|}{ GENDER } \\
\hline & Male & $\%$ & Female & $\%$ & Total & $\%$ \\
\hline $0-15$ & 278 & 8.5 & 265 & 8.1 & 544 & 16.5 \\
\hline $16-30$ & 491 & 14.9 & 498 & 15.1 & 989 & 30.0 \\
\hline $31-45$ & 299 & 9.1 & 396 & 12.0 & 695 & 21.1 \\
\hline $46-60$ & 239 & 7.3 & 399 & 12.1 & 638 & 19.4 \\
\hline $61-75$ & 169 & 5.1 & 155 & 4.7 & 324 & 9.8 \\
\hline$>75$ & 64 & 1.9 & 41 & 1.2 & 104 & 3.2 \\
\hline Total & 1540 & 46.8 & 1754 & 53.2 & 3294 & 100.0 \\
\hline
\end{tabular}

logistic regression, the moderate intensity "El Niño" phenomenon was associated with a statistically significant increase of medical attentions of viral warts $(p=0.038)$ and rosacea $(p=0.001)$. Finally, there was a significant increase of medical attentions of patients with dermatitis during spring season $(\mathrm{p}=0.000)$, and benign neoplasms $(p=0.011)$ during summer. Also, there was an increase of medical attentions of people with acne when the temperature was between 12 $14^{\circ} \mathrm{C}$ (Table 4). Also, there was an increase in the total number of medical attentions during summer months when the temperature is slightly elevated and the "El Niño" phenomenon typically presents. The humidity did not have any influence on the number of medical attentions (Graphic 1). Moreover, there was a partial correlation between the Oscillation Niño Index (ONI) and the number of medical attention, being more evident during the summer months of 2004, 2005 and 2007. In February 2006, there was an external factor affecting the tendency previously observed. The dermatology service carried out an extra health fair to rule out skin cancer increasing the influx of patients and affecting the correlation between ONI and medical attentions (Graphic 2).

\section{DISCUSSION}

The present investigation shows that certain dermatologic diseases are influenced by climatic and environmental factors. Associations between climatic phenomena such as "El Niño" and human health have

TABLE 2: Medical attentions in the Division of Dermatology/UNMSM according to the climatic phenomena. January 2004 - December 2007

\begin{tabular}{lll}
\hline CLIMATIC PHENOMENA & FREQUENCY OF MEDICAL ATTENTIONS & \% MEDICAL ATTENTIONS \\
\hline "El Niño" phenomenom & 1019 & 31.0 \\
- Severe & 0 & 0.0 \\
- Moderate & 95 & 2.9 \\
- Weak & 924 & 69.1 \\
- Absent & 2275 & \\
& & 5.7 \\
"La Niña" phenomenom & 234 & 0.0 \\
- Severe & 0 & 3.4 \\
- Moderate & 112 & 2.2 \\
- Weak & 72 & 94.4 \\
- Absent & 3110 & \\
& & 35.3 \\
Temperature & 1162 & 14.9 \\
- From 21 to $23{ }^{\circ} \mathrm{C}$ & 490 & 32.9 \\
- From 18 to $20^{\circ} \mathrm{C}$ & 1085 & 16.9 \\
- From 15 to $17^{\circ} \mathrm{C}$ & 557 & \\
- From 12 to $14{ }^{\circ} \mathrm{C}$ & & 37.6 \\
Season of the year & 1237 & 15.9 \\
Summer & 523 & 21.3 \\
Fall & 701 & 25.3 \\
Winter & 833 & \\
Spring & & \\
\hline
\end{tabular}


TABLE 3: Skin diseases in the study

\begin{tabular}{|c|c|c|}
\hline Diseases & Patients & $\%$ \\
\hline Other bacterial diseases & 6 & 0.15 \\
\hline Tuberculosis of skin and subcutaneous tissue & 4 & 0.09 \\
\hline Cutaneous bartonellosis [Verruga peruana] & 2 & 0.03 \\
\hline Infections with a predominantly sexual mode of transmission & 27 & 0.76 \\
\hline Herpesviral infection of genitalia & 22 & 0.67 \\
\hline Secondary syphilis of skin and mucous membranes & 3 & 0.09 \\
\hline Primary genital syphilis & 1 & 0.00 \\
\hline Viral infections & 539 & 16.36 \\
\hline Viral warts & 471 & 14.30 \\
\hline Herpes Zoster & 21 & 0.64 \\
\hline Molluscum contagiosum & 21 & 0.64 \\
\hline Mycoses & 245 & 7.32 \\
\hline Dermatophytosis & 98 & 2.98 \\
\hline Onychomycosis & 88 & 2.67 \\
\hline Pityriasis versicolor & 34 & 1.03 \\
\hline Protozoal diseases & 6 & 0.18 \\
\hline Cutaneous leishmaniasis & 6 & 0.18 \\
\hline Infestations & 48 & 1.46 \\
\hline Scabies & 45 & 1.37 \\
\hline Cutaneous myiasis & 2 & 0.06 \\
\hline Infections of the skin and subcutaneous tissue & 81 & 2.43 \\
\hline Cutaneous abscess, furuncle and carbuncle & 54 & 1.64 \\
\hline Cellulitis & 15 & 0.46 \\
\hline Impetigo & 10 & 0.30 \\
\hline Dermatologic manifestations of HIV & 14 & 0.43 \\
\hline VIH prurigo & 14 & 0.43 \\
\hline Benign neoplasms & 326 & 9.90 \\
\hline Other benign neoplasms of skin & 173 & 5.25 \\
\hline Melanocytic naevi & 153 & 4.64 \\
\hline Malignant neoplasms & 74 & 2.22 \\
\hline Basal cell carcinoma & 40 & 1.21 \\
\hline Squamous cell carcinoma & 14 & 0.39 \\
\hline Melanoma & 10 & 0.30 \\
\hline Bullous disorders & 47 & 1.43 \\
\hline Pemphigus vulgaris & 22 & 0.67 \\
\hline Pemphigus foliaceus & 10 & 0.30 \\
\hline Endemic pemphigus foliaceus & 7 & 0.21 \\
\hline Dermatitis & 583 & 17.70 \\
\hline Atopic dermatitis & 102 & 3.10 \\
\hline Allergic contact dermatitis & 100 & 3.04 \\
\hline Lichen simplex chronicus and prurigo & 93 & 2.82 \\
\hline Papulosquamous disorders & 126 & 3.83 \\
\hline Psoriasis & 84 & 2.55 \\
\hline Lichen planus & 18 & 0.55 \\
\hline Pityriasis rosea & 12 & 0.36 \\
\hline Urticaria and erythema & 62 & 1.88 \\
\hline Urticaria & 47 & 1.43 \\
\hline Other erythematous conditions & 15 & 0.43 \\
\hline Radiation-related disorders of the skin and subcutaneous tissue & 79 & 2.40 \\
\hline Actinic keratosis & 46 & 1.40 \\
\hline Other skin changes due to chronic exposure to nonionizing radiation & 30 & 0.91 \\
\hline Sunburn & 2 & 0.06 \\
\hline Disorders of skin appendages & 324 & 9.84 \\
\hline Acne & 157 & 4.77 \\
\hline Rosacea & 65 & 1.97 \\
\hline Nail disorders & 28 & 0.85 \\
\hline Other disorders of the skin and subcutaneous tissue & 707 & 21.46 \\
\hline Vitiligo & 196 & 5.95 \\
\hline Seborrhoeic keratosis & 119 & 3.61 \\
\hline Other disorders of pigmentation & 81 & 2.46 \\
\hline TOTAL & 3294 & 100 \\
\hline
\end{tabular}


TABLE 4: Climatic phenomena and associated skin diseases

\begin{tabular}{lllll}
\hline Climatic phenomena & Group of associated diseases & P value $(*)$ & Odds ratio & Confidence interval \\
\hline Moderate "El Niño" phenomena & Viral warts & 0.038 & 1.336 & $1.016-1.756$ \\
& Rosacea & 0.001 & 2.989 & $1.586-5.636$ \\
Temperature between $12-14^{\circ} \mathrm{C}$ & Acne & 0.036 & 3.989 & $1.094-14.549$ \\
Summer season & Benign neoplasms & 0.011 & 2.785 & $1.263-6.144$ \\
Spring season & Atopic dermatitis & 0.000 & 7.074 & $2.769-18.072$ \\
\hline
\end{tabular}

(*) Analysis with Forward conditional logistic regression.

been described before. These effects occur due to a complex interaction between the climatic phenomenon and factors that are specific to the affected population such as overcrowding, health condition and sanitary conditions. ${ }^{10}$

For instance, there is evidence that the "El Niño" influences on the occurrence of vector-borne diseases such as malaria. The elevated temperature and increased precipitations favor the environment for the plasmodium falciparum and its vector. ${ }^{11}$

It has been described an association between the "El Niño" phenomenon and other vector-borne diseases such as hemorrhagic fever with renal syndrome (HFRS) ${ }^{12}$, visceral leishmaniasis. ${ }^{13}$ Moreover, the "El Niño" has been associated with the presence of viral diseases such as hepatitis $\mathrm{A}^{14}$ and influenza. ${ }^{15}$ Previous studies have concluded the "El Niño" influences on the persistence of influenza aviar. ${ }^{11}$

In our study, the infectious diseases were the most common (29.3\%) and among them, viral warts were the most common diagnosis (14.3\%). This diagnosis was seen mainly in patients younger than 20 years of age. Similar results were found in other studies that showed viral warts to be predominant in children and adolescents. ${ }^{16}$ Currently, it is one of the most common reasons for consulting a dermatologist. ${ }^{17}$

The occurrence of viral warts was associated with the "El Niño" phenomenon (moderate). A previous study in Lima showed an increase in the number of consultations for viral warts when a strong "El Niño" phenomenon was present during the summer 1998. ${ }^{7}$ Indeed, another study in a pediatric population in Mexico showed that this diagnosis appears mainly in summer seasons. ${ }^{18}$ In these cases, an increase in the environmental temperature might create an adequate environment for the pathogenic virus to proliferate.

The dermatitis constituted the second most frequent disease group in our study (17.7\%). Within this group, atopic dermatitis was the most common (3.1\%). The disease is strongly associated with environmental factors such as pollution, allergen exposure and the increase of industrialization and housing development, all features present in Lima. ${ }^{19}$

An increase in dermatitis in general was found during spring season, and similar results were found

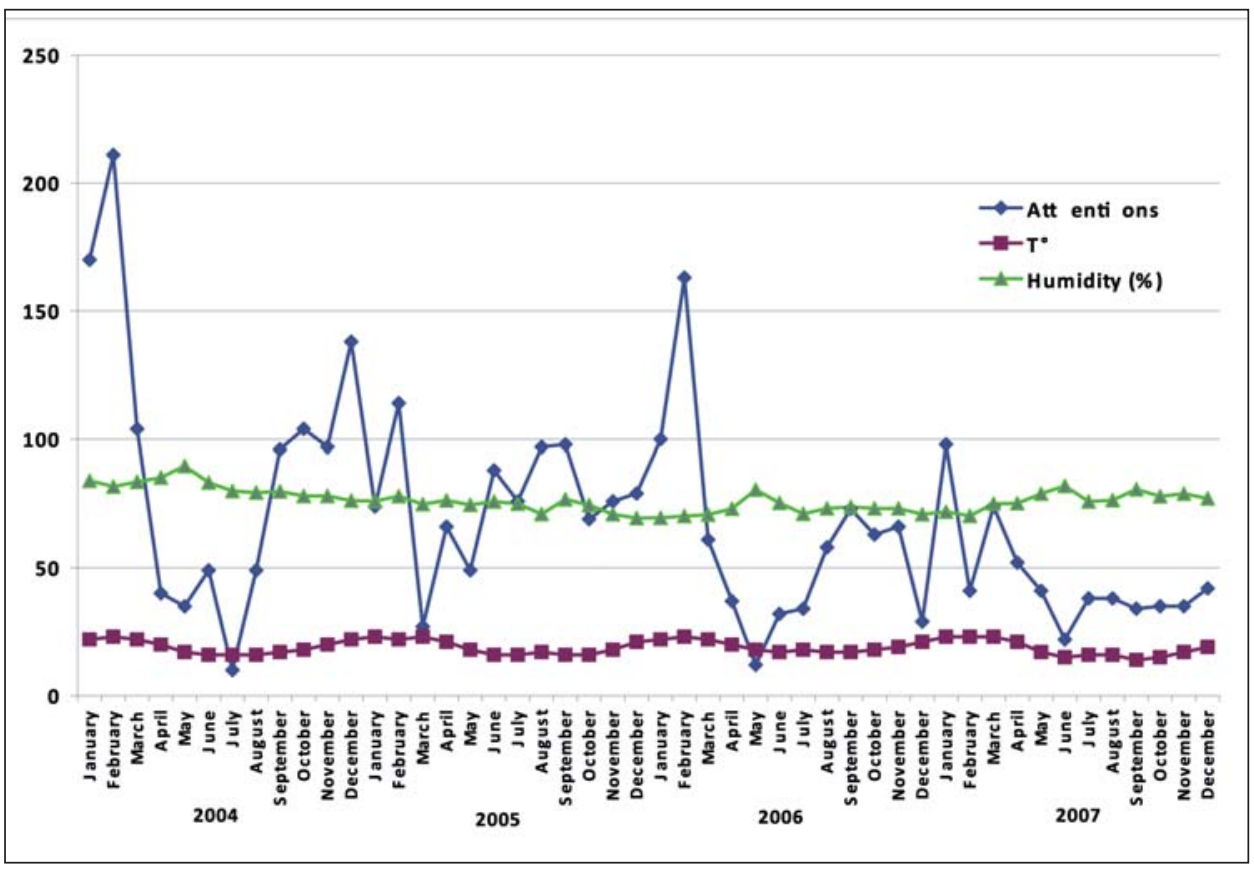

GRAPHIC 1: Diagram of temperature, humidity and medical attentions 


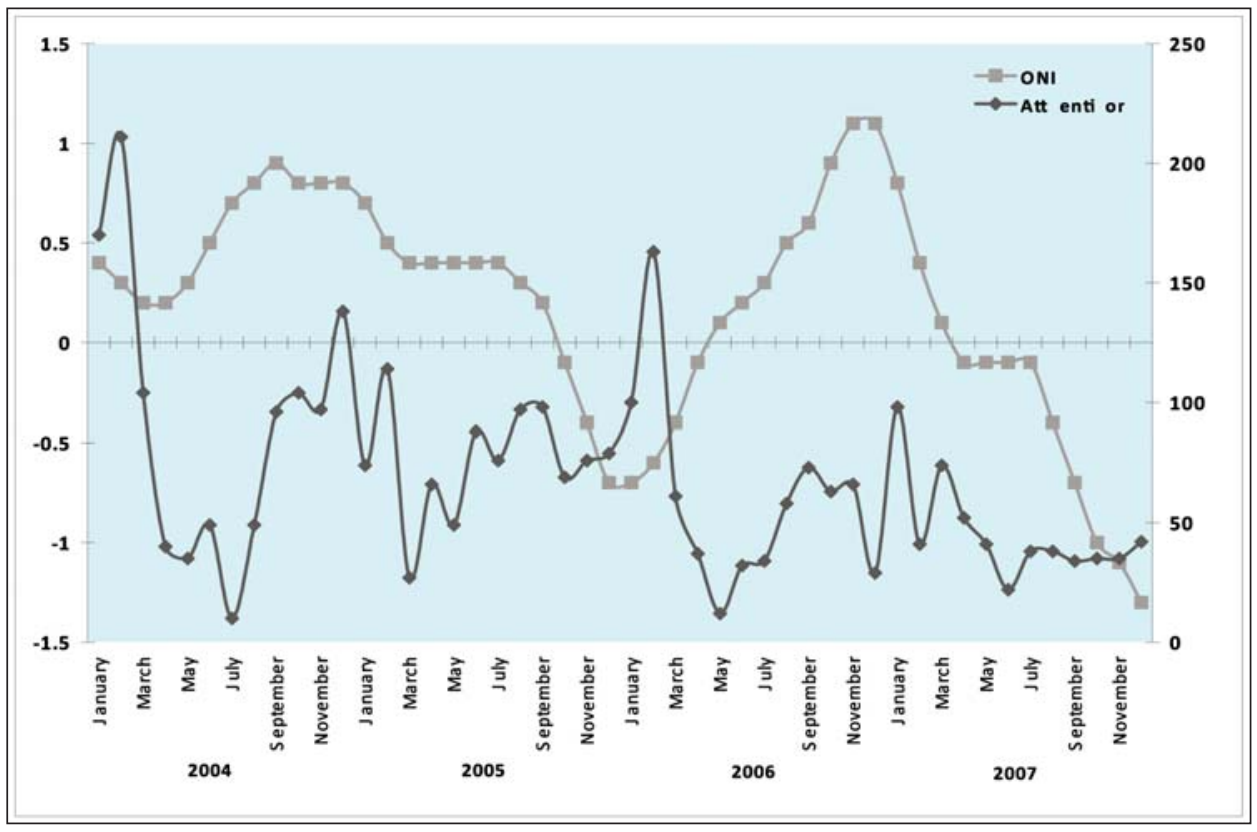

Graphic 2: Oscillation Niño Index (ONI) and number of medical attentions by Hellier ${ }^{(1)}$. This author proposes that this increase might be caused by a phase of instability provoked by the transition between winter to summer, resulting in an increase in the frequency of certain diseases. ${ }^{20}$

The increase of temperature caused by "El Niño" might have some influence on the increase of rosacea frequency. This finding was also observed in previous reports that showed an association between rosacea and heat exposure. ${ }^{21}$ The severity of rosacea was increased when the temperature raised secondary to the "El Niño" as well.

There was an increase in the medical consultations for people with benign skin neoplasms during summer months. In reference to melanocytic nevi, their presentation could be influenced by the higher exposure to solar radiation during those months. ${ }^{22}$ In addition, the number of consultations due to pigmented lesions increased because of aesthetic reasons and the implementation of skin cancer prevention campaigns. ${ }^{23}$ However, it is known that their genesis and development occur along years.

When the temperature was lower (between 12$140 \mathrm{O})$ there was an increase in the medical attentions of patients with acne. This might be because U.V. radiation induces inhibition of pathogenic bacteria and reduces excretion of grease. Therefore, when the radiation is less that might have some influence on the number of medical attentions for acne. ${ }^{24}$

It is important to consider for people with dermatitis that presence of environmental allergen during the spring might have an impact in the increase of medical consultations. In the case of viral warts, the increase of medical attentions was due to
The "El Niño". It might represent trigger factor. It is important to recognize that the weather might have some influence on the development and transmissibility of other viral diseases such as Hepatitis B.

All the data was obtained from patients who were seen at a general hospital. Our population was patients who were assessed for first time; however some of them have already a skin ailment for a long period of time. Therefore, it is important to consider that climatic changes might have some influence on the behavior of people when they seek for medical attention due to certain illnesses and it does not mean that they are causing certain skin ailments.

Our main limitation was the absence of a strong "El Niño" phenomenon during the period of study, such as the one occurred between 1997 and 1998. Our study was done during weak and moderate intensity phenomena. Additionally, global warming may shift the properties and dynamics of El Niño. Another limitation would be that this is a hospital based study; however, these types of studies are still important to determine the prevalence of diseases in a population. ${ }^{25}$

In conclusion, the climatic variations held influence over the occurrence of certain dermatologic diseases. The present study can guide specialists and general practitioners to anticipate the most common dermatologic diagnoses and to be prepared for the medical attention of these cases in determined seasons of the year. It may also help to make more accurate diagnoses and facilitate the use of therapeutic tools to in a timely manner. Additionally, it would help to orientate and to strengthen the academic training of health workers. 


\section{ACKNOWLEDGMENTS}

To Wilian Alva (Peruvian Society of Meteorology) for the critical review of the article. To Rosario Macetas, Alfonso Gomez, Wilian Alva, Gerardo Ronceros, Martha Uribe and Humberto Chía who collaborated with the medical attention of the patients.

\section{REFERENCES}

1. Hellier FF. Environment and skin disease. $\mathrm{Br} \mathrm{J}$ Dermatol 1940;52:107.

2. Hancox JG, Sheridan SC, Feldman SR, Fleischer AB Jr. Seasonal variation of dermatologic disease in the USA: a study of office visits from 1990 to 1998. Int J Dermatol. 2004;43:6-11.

3. Jha AK, Gurung D. Seasonal variation of skin diseases in Nepal: a hospital based annual study of out-patient visits. Nepal Med Coll J. 2006;8:266-8.

4. Instituto Nacional de Estadística e Informática (Perú). Estadísticas del Medio Ambiente (2004-2005); http://www.inei.gob.pe/web/BiblioInei/ListaItemBy TemaPalabra. $\quad$ asp?c $=9 \& \mathrm{tt}=$ Medio\%20Ambiente (accessed 30 April 2008).

5. National Oceanographic and Atmospheric Administration (NOAA). NOAA Niño page. What is El Niño?; http://www.pmel.noaa.gov/tao/elnino/el-ninostory.html (accessed 30 April 2008).

6. Gilberto Cabaniel G, Rada L, Blanco JJ, RodríguezMorales AJ. Impacto de los eventos de El Niño southern oscillation (ENSO) sobre la leishmaniosis cutánea en Sucre, Venezuela, a través del uso de información satelital, 1994 - 2003. Rev Peru Med Exp Salud Pública. 2005;22:32-8.

7. Bravo W, Bravo F. El efecto del fenómeno el niño en las enfermedades dermatológicas. Folia Dermatol Peru. 2001;12:24-9.

8. National Oceanographic and Atmospheric Administration (NOAA). NOAA satellite and information service. Monthly Climatic Data for the World. [cited 2008 April 30]. Available from: http://www7.ncdc.noaa.gov/IPS/MCDWPubs?action $=$ getpublication

9. National Oceanographic and Atmospheric Administration (NOAA). Climate Prediction Center. Monitoring \& Data. Ocean Niño Index. [cited 2008 April 30]. Available from: http://www.cpc.ncep.noaa.gov/products/analysis monitoring/ensostuff/ensoyears.shtml

10. Yang XB, Scherm H. El Niño and infectious disease. Science. 1997;275:739.

11. Rohani P. The link between dengue incidence and El Niño southern oscillation. PLoS Med. 2009; 6:e1000185.

12. Bi P, Parton KA, Tong S. El Nino-Southern Oscillation and vector-borne diseases in Anhui, China. Vector Borne Zoonotic Dis. 2005;5:95-100.

13. Franke CR, Ziller M, Staubach C, Latif M. Impact of the El Niño/Southern Oscillation on visceral leishmaniasis,
Brazil. Emerg Infect Dis. 2002;8:914-7.

14. Hu W, McMichael AJ, Tong S. El Niño Southern Oscillation and the transmission of hepatitis A virus in Australia. Med J Aust. 2004;180:487-8.

15. Zaraket H, Saito R, Tanabe N, Taniguchi K, Suzuki H. Association of early annual peak influenza activity with El Niño southern oscillation in Japan. Influenza Other Respi Viruses. 2008;2:127-30.

16. Sterling J, Handfield-Jones S, Hudson P. Guidelines for the management of cutaneous warts. $\mathrm{Br} \mathrm{J}$ Dermatol. 2001;144:4-11.

17. Julian CG. Dermatology in general practice. $\mathrm{Br} \mathrm{J}$ Dermatol. 1999;141:518-20.

18. Uriarte-Félix J , Sáez-de-Ocariz M, Durán-McKinster C, Orozco-Covarrubias L, Julián-González R. Variación estacional de las dermatosis más frecuentes en una consulta externa de Dermatología Pediátrica en México. Dermatol Pediatr Lat. 2005;3:21-5.

19. Levy RM, Gelfand JM, Yan AC. The epidemiology of atopic dermatitis. Clin Dermatol. 2003;21:109-15.

20. Hellier FF. Seasonal variation in the incidence of skin disease. Br J Dermatol. 1969;81:867.

21. Crawford GH, Pelle MT, James WD. Rosacea: I. Etiology, pathogenesis, and subtype classification. J Am Acad Dermatol. 2004;51:327-41.

22. Armstrong BK, de Klerk NH, Holman CD. Etiology of common acquired melanocytic nevi: constitutional variables, sun exposure, and diet. J Natl Cancer Inst. 1986;77:329-35.

23. Hall G, Hull C, Siegel ER, Smoller BR, Johnson SM. Seasonal effect upon excision of acquired melanocytic proliferations. Int J Dermatol. 2003;42:686-90.

24. Foley P, Zuo Y, Plunkett A, Merlin K, Marks R. The Gfesser M,Worret WI. Seasonal variations in the severity of acne vulgaris. Int J Dermatol. 1996;35:116-7.

25. Kumarasinghe SP. Meteorological parameters and the pattern of dermatology clinic attendance through a calendar year: a Sri Lankan experience. Int J Dermatol. 2000;39:497-500.

MAILING ADDRESS / ENDEREÇO PARA CORRESPONDÊNCIA:

Alex G. Ortega-Loayza, MD

Department of Internal Medicine

Virginia Commonwealth University

PO Box 980509

Richmond, VA 23298-0509

Tel./Fax: 919619 4096; 8048284926

E-Mail: aortegaloayza2@mcvb-vcu.edu

How to cite this article/Como citar este artigo: Gutierrez EL, Galarza C, Ramos W, Mendoza M, Smith ME, OrtegaLoayza AG. Influence of climatic factors on the medical attentions of dermatologic diseases in a hospital of Lima, Peru. An Bras Dermatol. 2010;85(4):461-8. 